https://helda.helsinki.fi

\title{
Overview of Primary Education (Finland)
}

\section{Varjo, Janne}

Bloomsbury Publishing

2019-04-02

Varjo , J , Kalalahti , M \& Kauko , J 2019 , Overview of Primary Education (Finland) . in J

Kauko , M T Tatto \& I Menter (eds), Bloomsbury Education and Childhood Studies : Articles

. Bloomsbury Publishing , London . https://doi.org/10.5040/9781350995932.0018

http://hdl.handle.net/10138/309018

https://doi.org/10.5040/9781350995932.0018

acceptedVersion

Downloaded from Helda, University of Helsinki institutional repository.

This is an electronic reprint of the original article.

This reprint may differ from the original in pagination and typographic detail.

Please cite the original version. 
Varjo, J., Kalalahti, M. \& Kauko, J. 2019. Overview of Primary Education (Finland). Bloomsbury

Education and Childhood Studies. www.becs-bloomsbury.com

\section{Key words:}

Comprehensive school system, Local education authorities, Class with a special emphasis, threetiered support model, sample-based thematic evaluation

\section{Glossary terms:}

Class with a special emphasis: Municipalities, through their elected education boards, decide on the allocation of lesson hours at schools in their areas. Classes with a special emphasis function as separate streams within regular municipal schools, and they have more lessons (for instance in music, sports, science, languages or art) than the National Core Curriculum requires. (Varjo, Kalalahti \& Silvennoinen 2014.)

Comprehensive school system: An education system in which the schools are publicly funded and are commonly not able to select their intake on the basis of academic achievement or aptitude. It is the opposite of a selective school system, into which admission is based on selection criteria (Kalalahti, Silvennoinen, Varjo \& Rinne 2015).

The Finnish Education Evaluation Centre: The Finnish Education Evaluation Centre is an independent agency responsible for the evaluation of education. It operates as a separate unit within the Finnish National Agency for Education. It carries out evaluations related to education including the operations of education providers, from early childhood education to higher education. (https://karvi.fi/en/fineec/)

The Finnish National Agency for Education: The National Agency works under the auspices of the Ministry of Education and Culture. One of its main duties is to work on the national core curricula for pre-primary education, basic education, general upper secondary education, and the curricula for preparatory education for immigrants and morning and afternoon activities for school children (https://www.oph.fi/english/curricula_and_qualifications).

Municipality: An administrative division having corporate status and powers of self-government as granted by the national laws to which it is subordinate. In 2018, Finland consists of 311 municipalities. They are the main providers of basic education (Varjo \& Kalalahti 2018).

\section{Overview of Primary Education (Finland)}

\section{Structure of primary education}

Primary education in Finland refers to the first six years of basic, universal education in a nine-year comprehensive school system which is meant for children aged between seven and 16 years. Primary education pupils are usually taught in year groups. All schools follow the National Core Curriculum, which includes the objectives and core contents of all subjects. The education providers draw up their own curricula within the framework of the National Core Curriculum (Kalalahti, Silvennoinen, Varjo \& Rinne 2015). Education is provided to pupils for free, as are learning materials, daily school meals, health and welfare services and transport from home to school if the way to school is long or dangerous (EURYDICE 2018).

Primary education is mainly public and is provided by municipalities (96 per cent in 2009, according to Kumpulainen 2011). Private schools are mostly schools with a specific religious or pedagogical 
emphasis. According to the OECD definition, they are government-dependent private schools, that is, institutions that receive more than 50 per cent of their funding from government agencies (Musset 2012). A key feature of the national education culture is to ensure there are equal opportunities for all (Simola et al. 2017). Individual support measures are in place to guarantee that every pupil can reach their full potential. Within the three-tiered support model, all pupils have the right to general support. If necessary, pupils will also be given intensified support and special support. Differences between schools are small and the quality of teaching is high across the country. (EURYDICE 2018.)

\section{National strategic framework}

Education policy is defined by Parliament and Government. The Ministry of Education and Culture and the Finnish National Agency for Education are responsible for the implementation of the policy aims. The Agency works with the Ministry to develop educational objectives, content and methods for early childhood, pre-primary, basic, upper secondary and adult education. At the regional level, Regional State Administrative Agencies draw up regional development plans in co-operation with the local authorities within their respective regions, and the state authorities.

Local administration is the responsibility of the municipalities. They make the decisions on the allocation of funding, local curricula and recruitment of personnel. The municipalities also have the autonomy to delegate decision-making power to the schools. (FNAE 2017a.) Founding new municipal schools is a decision made by the local administration while new private schools need to be authorized by the Government.

\section{Demographics}

At the end of 2017, there were 2,276 comprehensive schools with 539,600 pupils. Most pupils attending primary schools (grades one to six) are aged between seven and 12. Approximately ten per cent of the primary school pupils received intensified support and seven per cent received special support 2017 (OSF 2018a; 2018b). Table 1 displays the number of comprehensive schools based on their size and the grades they host. Basic education is provided within a single structure, that is, there is no division between primary and lower secondary education (Varjo \& Kalalahti 2018).

Table 1. Number of comprehensive schools according to the size and grades of the school. (Statistics Finland 2018).

\begin{tabular}{|l|r|r|r|r|r|r|r|}
\hline $\begin{array}{l}\text { Grades / } \\
\text { number } \\
\text { of pupils }\end{array}$ & \multicolumn{1}{|c|}{$\begin{array}{c}1-19 \\
\text { pupils }\end{array}$} & $\begin{array}{l}20-49 \\
\text { pupils }\end{array}$ & $\begin{array}{l}50-99 \\
\text { pupils }\end{array}$ & $\begin{array}{c}100- \\
299 \\
\text { pupils }\end{array}$ & $\begin{array}{c}300- \\
499 \\
\text { pupils }\end{array}$ & $\begin{array}{c}500- \\
999 \\
\text { pupils }\end{array}$ & $\begin{array}{c}1000- \\
\text { pupils }\end{array}$ \\
\hline $\begin{array}{l}\text { Primary } \\
\text { (grades 1- } \\
6 \text { ) }\end{array}$ & 37 & 319 & 352 & 592 & 233 & 56 & 0 \\
\hline $\begin{array}{l}\text { Lower } \\
\text { secondary } \\
(7-9)\end{array}$ & 1 & 1 & 12 & 99 & 106 & 27 & 0 \\
\hline $\begin{array}{l}\text { Primary } \\
\text { and lower } \\
\text { secondary } \\
1-9\end{array}$ & 7 & 11 & 17 & 125 & 105 & 165 & 10 \\
\hline
\end{tabular}




\section{Trajectories}

One year of pre-primary education is compulsory for children from the age of six. In pre-primary education children adopt basic skills, knowledge and capabilities from several areas of learning in accordance with their age and abilities. All children are allocated a place in a neighborhood school at the beginning of their primary education, but families in larger cities often use their right to apply to a particular school. School choice is commonly made by applying for access to a class with a special emphasis. Applying for a class with a special emphasis is possible at three stages: at the beginning of primary education, at the beginning of grade three, and at the beginning of grade seven (Koivuhovi, Vainikainen, Kalalahti \& Niemivirta 2017).

\section{Curriculum}

The National Core Curriculum, drawn up by the Finnish National Agency for Education, is the main content-steering instrument in comprehensive education system. Education providers are obliged to prepare their own curricula for pre-primary and basic education within the framework of the National Core Curriculum. It leaves room for local variations and therefore individual schools and teachers have considerable freedom in designing their own curricula and instruction.

The National Core Curriculum includes the objectives and core contents of all subjects, as well as the principles of pupil assessment, special-needs education, pupil welfare and educational guidance. The principles of a good learning environment, working approaches and the concept of learning, are also addressed. The National Core Curriculum for basic education was updated in 2014. (FNAE 2017a.) It follows the current trend of competence-based curriculum and key competencies promoted by the OECD (Uljens \& Rajakaltio 2017).

\section{Teachers and other school personnel}

For grades one to six, most teaching is done by classroom teachers, while some subjects such as foreign languages are commonly taught by subject teachers. A classroom teacher might also have subject teacher competency for some subjects. All pupils have the right to general support and their welfare is supported by multi-professional welfare groups.

In primary education, teachers are required have a master's degree in education or another degree that includes extensive pedagogical studies. Only around 11 per cent of applicants who take an exam for entry to university education faculties were admitted. Of these, 78 per cent were women. The high level of training is seen as necessary as teachers in Finland have strong professional autonomy. In 2016, the 97 per cent of Finnish-speaking classroom teachers and 89 per cent of Swedish-speaking classroom teachers were formally qualified. At most levels of education, teachers are required to participate in inservice training every year (FNAE 2017b; Kumpulainen 2017).

\section{Teaching in primary schools}

The number of teaching hours in primary education in Finland is below the OECD average. There are 190 school days in a year. Teachers are not obliged to be at school when they have no lessons or other duties. In addition to teaching, the tasks of teachers include planning of instruction and pre- and postclass work. Furthermore, the school's internal development responsibilities, and cooperation with colleagues, parents/guardians and other partners, such as staff in pupil and social welfare services, form an integrated part of a teacher's work (FNAE 2017b).

\section{Language of instruction}

Finland has two official languages, Finnish and Swedish. Approximately five per cent of students in basic and upper secondary education attend a school at which Swedish is the language of instruction. Both language groups also have their own institutions at the higher education level. In addition, there are a few educational institutions at which all or at least some instruction is provided in a foreign 
language, most commonly in English. Municipalities are also obliged to provide education in the Sámi language in the Sámi Homeland in Lapland. Moreover, the educational opportunities for Roma and other minorities as well as for people who use sign language, must be ensured by law. Education providers also arrange preparatory education for migrants to enable them to enter comprehensive or upper secondary education (FNAE 2017a; Zacheus, Kalalahti \& Varjo 2018).

\section{Relationships with other agencies}

The National Institute for Health and Welfare is responsible for the coordination and development of national student welfare services in cooperation with the Finnish National Agency for Education. The Regional State Administrative Agencies oversee that education providers provide student welfare in accordance with the curriculum.

\section{Internal and external accountability}

In Finland, there is little external control, such as school or textbook inspections. During primary education there are no test-based accountability measures and no national standardized tests for age cohorts. The most important quality assurance mechanism is the self-evaluation carried out by the education providers themselves. The education provider is obliged to evaluate its own education and its effectiveness as well as to take part in external, sample-based thematic evaluations.

The Finnish Education Evaluation Centre was established in 2014 to be responsible for national evaluations of education at all levels. The aim of the evaluations is to develop education and to support learning while ensuring the high quality of education. Moreover, the evaluations produce information for decision-making on education as well as development work and international comparison (Simola, Kauko, Varjo, Kalalahti \& Sahlström 2017).

Teachers are not evaluated through external or formal measures. The principals of the institutions are also pedagogical heads and thus the quality of teaching is their responsibility. At many schools, principals and teachers conduct development discussions annually, during which they review the past year and the objectives for the coming year.

\section{Community involvement}

As part of local governance, municipalities have politically-representative education boards which are responsible for preparing school-related issues for the local council. Municipally-provided schools are not obliged by law to have school boards. Co-operation with parents is coordinated at the schools through parent nights and personal contacts. Some organizations, such as the Finnish Parents' League (founded in 1907) aim to combine the resources of parents in order to build a good learning and growing environment for all children by influencing national opinion and decisions. It has nearly 1,400 parent association members (NBE 2011).

\section{Further reading and online resources}

Basic Education Act. Law 628/1998. http://www.finlex.fi/en/laki/kaannokset/asiasanat.php?start=a\&id=580163 [accessed 14 October 2018]

The Finnish National Agency for Education (2014), National Core Curriculum for basic education, https://www.oph.fi/english/curricula and qualifications/basic education [accessed 14 October 2018] OECD (2018), Finland. Paris: Organization for Educational Development and Cooperation. http://www.oecd.org/finland/ [accessed 14 October 2018] Sahlberg, P. (2011), Finnish Lessons: What can the world learn from educational change in Finland? New York, NY: Teachers College Press.

Simola, H., Kauko, J., Varjo, J., Kalalahti, M. \& Sahlström, F. (2017), Dynamics in Education Politics - Understanding and explaining the Finnish case. London: Routledge. 
Vipunen. 2018. Vipunen - Education Statistics Finland.

https://vipunen.fi/en-gb/ [accessed 14 October 2018]

\section{References}

EURYDICE (2018), Finland Overview. Brussels: EACEA European Unit of Eurydice in Brussels, https://eacea.ec.europa.eu/national-policies/eurydice/content/finland_en [accessed 14 October 2018].

FNAE (The Finnish National Agency for Education) (2017a), Finnish Education in a nutshell, Helsinki: The Finnish National Agency for Education, https://www.oph.fi/download/146428_Finnish_Education_in_a_Nutshell.pdf [accessed 14 October 2018].

FNAE (The Finnish National Agency for Education) (2017b), Teachers in Finland - Trusted Professionals, Helsinki: The Finnish National Agency for Education, https://www.oph.fi/download/148962_Teachers_in_Finland.pdf [accessed 14 October 2018].

Kalalahti, M., Silvennoinen, H., Varjo, J. and Rinne, R. (2015), 'Education for all? Urban parental attitudes towards universalism and selectivism in the Finnish comprehensive school system', in Seppänen, P., Carrasco, A., Kalalahti, M., Rinne, R. and Simola, H. (eds), Contrasting Dynamics in Education Politics of Extremes: school choice in Chile and Finland, Rotterdam: SensePublishers, 205-224.

Koivuhovi, S., Vainikainen, M.-P., Kalalahti, M. and Niemivirta, M. (2018), 'Changes in Children's Agency Beliefs and Control Expectancy in Classes with and without a Special Emphasis in Finland from Grade Four to Grade Six', Scandinavian Journal of Educational Research, Print ahead. DOI: 10.1080/00313831.2017.1402364

Kumpulainen, T. (2011) (ed.), Koulutuksen määrälliset indikaattorit [Quantitative Indicators of Education]. Helsinki: National Board of Education.

Kumpulainen, T. (2017) (ed.), Opettajat ja rehtorit Suomessa 2016 [Teachers and principals in Finland 2016]. Helsinki: The Finnish National Agency for Education.

Musset, P. (2012), School Choice and Equity: Current Policies in OECD Countries and a Literature Review. OECD Education Working Papers No. 66. Paris: OECD.

NBE (National Board of Education) (2011), The School of Opportunities - Towards every learner's full potential, Helsinki: National Board of Education, https://www.oph.fi/download/134584_the_school_of_opportunities.pdf [accessed 14 October 2018].

OSF (Official Statistics of Finland) (2018a), Providers of education and educational institutions, Helsinki: Statistics Finland.

http://www.stat.fi/til/kjarj/2017/kjarj_2017_2018-02-13_tie_001_en.html [accessed 14 October 2018].

OSF (Official Statistics of Finland) (2018b), Special education,

Helsinki: Statistics Finland, http://www.stat.fi/til/erop/index_en.html [accessed 14 October 2018]. 
OSF (Official Statistics of Finland) (2004), Opettajat ja muu henkilökunta [Teachers and other personnel]. Helsinki: Statistics Finland. http://www.stat.fi/til/ope/2004/ope_2004_2006-0630_tie_001.html [accessed 14 October 2018].

Simola, H., Kauko, J., Varjo, J., Kalalahti, M. and Sahlström, F. (2017), Dynamics in Education Politics - Understanding and explaining the Finnish case, London: Routledge.

Statistics Finland (2018), 'Peruskoulut, lukiot, ammatiliset oppilaitokset ja kansanopistot opiskelijamäärillä mitatun oppilaitoksen koon mukaan 2005-2017', Database: Providers of education and educational institutions,

http://pxnet2.stat.fi/PXWeb/pxweb/en/StatFin/StatFin_kou_kjarj/statfin_kjarj_pxt_002_fi.px/?rxid $=1307 \mathrm{e} 282-\mathrm{a} 7 \mathrm{f9}-4 \mathrm{c} 15$-bcce-4380aafa954e [accessed 14 October 2018].

Uljens, M. and Rajakaltio, H. (2017), 'National Curriculum Development as Educational Leadership: A Discursive and Non-affirmative Approach', in Uljens M. and Ylimaki R. (eds.), Bridging Educational Leadership, Curriculum Theory and Didaktik. Educational Governance Research 5, Cham: Springer, 411-437.

Varjo, J. and Kalalahti, M. (2018), 'The art of governing local education markets - municipalities and school choice in Finland', Education Inquiry, Print ahead https://doi.org/10.1080/20004508.2018.1514907 [accessed 14 October 2018].

Varjo, J., Kalalahti, M. \& Silvennoinen, H. 2014. 'Families, school choice and democratic iterations on the Right to Education and Freedom of Education in Finnish municipalities'. Journal of School Choice, 8(1): 20-48.

Zacheus, T., Kalalahti, M. and Varjo, J. (2017), 'Cultural minorities in Finnish opportunity structures', Research on Finnish Society, 10(2): 132-144.

Table 1. Number of comprehensive schools according to the size and grades of the school. (Statistics Finland 2018).

\begin{tabular}{|l|r|r|r|r|r|r|r|}
\hline $\begin{array}{l}\text { Grades / } \\
\text { number } \\
\text { of pupils }\end{array}$ & $\begin{array}{c}1-19 \\
\text { pupils }\end{array}$ & $\begin{array}{c}20-49 \\
\text { pupils }\end{array}$ & $\begin{array}{c}50-99 \\
\text { pupils }\end{array}$ & $\begin{array}{c}100- \\
299 \\
\text { pupils }\end{array}$ & $\begin{array}{c}\text { 300- } \\
499 \\
\text { pupils }\end{array}$ & $\begin{array}{c}500- \\
999 \\
\text { pupils }\end{array}$ & $\begin{array}{c}1000- \\
\text { pupils }\end{array}$ \\
\hline $\begin{array}{l}\text { Primary } \\
\text { (grades 1- } \\
6 \text { ) }\end{array}$ & 37 & 319 & 352 & 592 & 233 & 56 & 0 \\
\hline $\begin{array}{l}\text { Lower } \\
\text { secondary } \\
(7-9)\end{array}$ & 1 & 1 & 12 & 99 & 106 & 27 & 0 \\
\hline $\begin{array}{l}\text { Primary } \\
\text { and lower } \\
\text { secondary } \\
1-9\end{array}$ & 7 & 11 & 17 & 125 & 105 & 165 & 10 \\
\hline
\end{tabular}


